Article

\title{
Total Oxidation of Dichloromethane over Silica Modified Alumina Catalysts Washcoated on Ceramic Monoliths
}

\author{
Zouhair El Assal ${ }^{1,2} \mathbb{1 D}^{\circ}$, Satu Ojala ${ }^{1, *}$, Asmaa Drif ${ }^{3}$, Mohamed Zbair ${ }^{1,4}{ }^{(0)}$, Mohammed Bensitel ${ }^{4}$, \\ Laurence Pirault-Roy ${ }^{3}$, Tuomas Nevanperä ${ }^{1}$, Satu Pitkäaho ${ }^{1}$, Riitta L. Keiski ${ }^{1}$ \\ and Rachid Brahmi ${ }^{4}$ \\ 1 Faculty of Technology, Environmental and Chemical Engineering, University of Oulu, P. O. Box 4300, \\ FI-90014 Oulu, Finland; zouhair.elassal@oulu.fi (Z.A.); zbair.mohamed@gmail.com (M.Z.); \\ tuomas.nevanpera@oulu.fi (T.N.); satu.pitkaaho@oulu.fi (S.P.); riitta.keiski@oulu.fi (R.L.K.) \\ 2 Thule Institute, P. O. Box 7300, FI-90014 Oulu, Finland \\ 3 Institute of Chemistry of Poitiers, Materials and Natural Resources, CNRS-UMR 7285, University of Poitiers \\ B27, Rue Michel Brunet, CEDEX 9, 86073 Poitiers, France; drif.asmaa@gmail.com (A.D.); \\ laurence.pirault@univ-poitiers.fr (L.P.-R.) \\ 4 Laboratory of Catalysis and Corrosion of Materials (LCCM), Department of Chemistry, Faculty of Sciences, \\ University of Chouaiib Doukkali El Jadida, BP 20, 24000 El Jadida, Morocco; mbensitel@yahoo.fr (M.B.); \\ rachid.brahmi@univ-poitiers.fr (R.B.) \\ * Correspondence: satu.ojala@oulu.fi; Tel.: +358-503-506-098
}

Received: 8 July 2018; Accepted: 17 August 2018; Published: 20 August 2018

\begin{abstract}
Silica modified alumina was used in this study for coating of a cordierite monolith substrate with two different channel densities. The performance of the prepared monolith catalysts was evaluated in catalytic total oxidation of dichloromethane before and after Pt impregnation. The characteristics similar to the powder form catalysts were kept rather successfully after washcoating the monolith as evidenced by electron microscopy (FESEM) and $\mathrm{N}_{2}$ physisorption. A dichloromethane (DCM) conversion of higher than $80 \%$ at $500{ }^{\circ} \mathrm{C}$ was reached over all the catalysts with $200 \mathrm{cpsi}$. The maximum conversion was obtained with the catalyst containing $10 \mathrm{~mol} \%$ of silica. The total amount of major byproducts $\left(\mathrm{CO}, \mathrm{CH}_{3} \mathrm{Cl}\right.$ and $\left.\mathrm{CH}_{2} \mathrm{O}\right)$ were slightly decreased by increasing the silica loading, and remarkably after $\mathrm{Pt}$ impregnation. After impregnation of $\mathrm{Pt}$, the $\mathrm{HCl}$ yields were increased for two samples with the higher loading of silica (10 and $15 \mathrm{~mol} \%)$ and reached the maximum when silica loading was $10 \%$. Even though Pt impregnation did not significantly affect the DCM conversion, it improved the selectivity. Comparison between the two substrates (200 and $600 \mathrm{cpsi}$ ) evidenced that the key parameters of the monolith influencing the DCM oxidation are low value of open fraction area, hydraulic diameter, thermal integrity factor and high value of mechanical integrity factor and geometric surface area.
\end{abstract}

Keywords: alumina-silica oxide; cordierite; CVOC abatement; dichloromethane; sol-gel method

\section{Introduction}

Dichloromethane (DCM) belongs to the group of chlorinated volatile organic compounds (CVOC). DCM is a transparent liquid, which has a soft sweet odor and it evaporates easily in normal conditions [1-3]. DCM is rather widely used in industry as paint stripper and remover, the propellant in aerosols, in film coatings, as a degreasing agent in the electronics industry, for blowing of polyurethane foam, but also as a metal-cleaning solvent and in the decaffeination process of coffee and tea [1-4]. It has been reported that the average indoor concentration of DCM is about three times higher than 
the outdoor values (below $5 \mu \mathrm{g} \mathrm{m}^{-3}$ ) [3,5]. Since the people in industrial countries spend most of their time indoors, the health effects of DCM should not be forgotten. The effects of DCM on human health depend largely on the exposure time. It can cause irritation of the skin, eyes, respiratory tract and it can lower the consciousness and cause dermatitis. DCM can also affect the central nervous system and the liver and it can be carcinogenic [6-8].

Catalytic oxidation is one of the possible technologies for the treatment of CVOCs. The advantage of catalytic oxidation is the lower energy needed for the CVOC treatment compared with thermal oxidation. In addition, the catalytic material can be tailored in such a way that it efficiently oxidizes CVOCs into the wanted oxidation products without formation of harmful byproducts, such as dioxins. Different types of catalysts have been tested for DCM oxidation such as alumina [9-20], titania [21-24], and ceria-based catalysts [7,11,25]. In addition, $\mathrm{MgO}[26,27]$ and zeolites [28-33] have been considered. Depending on the study, these oxides are used alone or mixed with other oxides, such as zirconium, magnesium, copper, silicon oxides, and others. These earlier studies also provide knowledge on the effects of experimental conditions such as space velocity (GHSV), DCM concentration or water addition on the DCM oxidation, but also on the beneficial properties of the catalysts, such as the acidity of the support $[8,10,16,30]$. From the noble metals, the most frequently used metal for oxidation purposes, $\mathrm{Pt}$, was found to be more active than Pd in DCM oxidation [34]. We have earlier studied DCM oxidation over $\mathrm{Pt}$ catalysts supported on $\mathrm{Al}_{2} \mathrm{O}_{3}, \mathrm{TiO}_{2}, \mathrm{CeO}_{2}$ and $\mathrm{MgO}$ (in powder form) [35]. From these studied catalysts, $\mathrm{Pt} / \mathrm{Al}_{2} \mathrm{O}_{3}$ was found to be the most active and selective. From the practical point of view, when the powder form catalyst is presenting a high performance in the abatement of an air pollutant at laboratory scale, it should be modified in an applicable form for industrial use. This can be performed for example by coating the catalytic material on a monolith.

In this work, silica modified alumina catalysts washcoated on ceramic monoliths (made mainly of synthetic cordierite) was used to approach the final use of the catalyst. The cordierite monoliths $\left(2(\mathrm{MgO}) \cdot 2\left(\mathrm{Al}_{2} \mathrm{O}_{3}\right) \cdot 5\left(\mathrm{SiO}_{2}\right)\right)$ are often used in industrial applications due to their numerous advantages, such as low pressure drop (large open frontal area; OFA) [36], insensitivity to temperature changes due to almost zero thermal expansion coefficient [37], lower price than that of metallic monoliths and their greater resistance in aggressive reaction media. Cordierite allows also good bonding between the substrate and coating materials [38]. Furthermore, precious metals present in the coating materials cannot be introduced to the cordierite substrate and the monolith material cannot migrate to the coating phase, even in severe conditions such as reducing atmosphere or in the presence of sulphur compounds. The low thermal expansion coefficient of the cordierite substrate offers a resistance to thermal shock and good stability of washcoat., Cordierite substrate has higher melting point than $1450{ }^{\circ} \mathrm{C}[39,40]$. For these reasons, the cordierite monolith was chosen as the catalyst substrate in this study. In this work, the cordierite monoliths were washcoated by alumina-silica with different loadings of silica $\left(\mathrm{SiO}_{2}\right)$ before impregnation of Pt. The prepared samples were characterized and tested in DCM oxidation to find out the information relevant to the industrial application of the studied materials. The goal of the washcoating was to preserve the beneficial properties of powder form catalyst after washcoating it on a monolith substrate.

\section{Results and Discussion}

The main part of the characterization was made for the sol used for monoliths' washcoating. Before characterization the same calcination procedure was done for the sol than for the washcoated monoliths. Later, these calcined sols are called as 'catalyst powders'. After preparation of sol, washcoating and calcining the monoliths, Pt was added on the washcoated monoliths by wet impregnation. Pt-impregnated monoliths were further calcined and reduced before the testing. Pt was not impregnated on the catalyst powders. The details on the catalyst preparation and washcoating procedure of the monoliths are given at the end of this paper. 


\subsection{Characterisation of Catalyst Powders}

To verify the success of the preparation, the compositions of the doped and calcined alumina samples were determined by XRF technique. The molar ratio of alumina and silica in AlSix powders are presented in Table 1. A good agreement between the targeted and analysed amounts can be observed based on the analysis results.

Table 1. Chemical composition of the prepared materials.

\begin{tabular}{ccccccc}
\hline & \multicolumn{2}{c}{ AlSi5 } & \multicolumn{2}{c}{ AlSi10 } & \multicolumn{2}{c}{ AlSi15 } \\
\cline { 2 - 7 } & XRF & Target & XRF & Target & XRF & Target \\
\hline Molar amount of $\mathrm{SiO}_{2}(\%)$ & 6 & 5 & 12 & 10 & 18 & 15 \\
Molar amount of $\mathrm{Al}_{2} \mathrm{O}_{3}(\%)$ & 94 & 95 & 88 & 90 & 82 & 85 \\
\hline
\end{tabular}

The textural and structural properties of AlSix samples in powder forms are summarized in Table 2. High surface areas were obtained for all the prepared samples. Doping alumina by a small amount of silica enhanced the surface area and porous volume when $\mathrm{Si} / \mathrm{Al}$ molar ratio was increased. However, the total porous volume and pore diameter remained quite similar, around $0.4 \mathrm{~cm}^{3} \mathrm{~g}^{-1}$ and $5 \mathrm{~nm}$ for the mixed oxides, respectively. The $\mathrm{N}_{2}$-adsorption-desorption isotherms of the AlSix $(x: 5,10,15)$ powder samples exhibited isotherm of Type IV indicating the presence of mesoporous material according to the International Union of Pure and Applied Chemistry (IUPAC). The H2-type hysteresis loop is specific for relatively large pores with a narrow opening (neck of bottle) or clusters of small spheroidal particles [41,42]. The isotherm of AlSi15 sample is shown in Figure 1 as an example. The other AlSix samples showed similar characteristics.

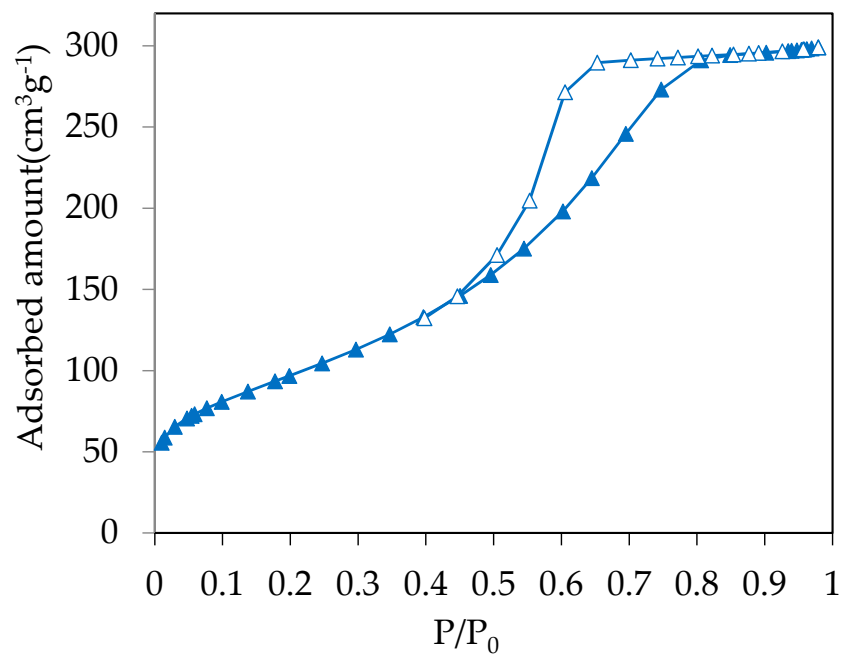

Figure 1. $\mathrm{N}_{2}$-adsorption-desorption isotherms for AlSi15 support (filled symbols indicate adsorption, open symbols indicate desorption).

Table 2. Characteristic properties of powders used as coating phase.

\begin{tabular}{|c|c|c|c|c|}
\hline & $\mathrm{S}_{\mathrm{BET}} / \mathrm{m}^{2} \mathrm{~g}^{-1}$ & $\begin{array}{c}\text { Porous } \\
\text { Volume } / \mathrm{cm}^{3} \mathrm{~g}^{-1}\end{array}$ & $\begin{array}{c}\text { Pore } \\
\text { Size/nm }\end{array}$ & $\begin{array}{l}\text { Crystallite Size } \\
\text { (XRD)/nm }\end{array}$ \\
\hline $\mathrm{Al}_{2} \mathrm{O}_{3}$ & 230 & 0.23 & 4 & 4 \\
\hline AlSi5 & 300 & 0.49 & 7 & 4 \\
\hline AlSi10 & 320 & 0.42 & 5 & 4 \\
\hline AlSi15 & 350 & 0.42 & 5 & 5 \\
\hline $\mathrm{SiO}_{2}$ & 540 & 0.26 & 2 & - \\
\hline
\end{tabular}


In order to identify the crystalline phases and estimate the crystallite size, XRD analyses were performed for all AlSix samples. All the diffractogram patterns (Figure 2) show the presence of a $\gamma$-phase of alumina (ICDD: 00-50-0741) accompanied with a significant part of an amorphous phase, probably containing silica in accordance with diffractogram of pure silica, which exhibits such amorphous phase. The crystallite size of the prepared materials (basically for $\gamma-\mathrm{Al}_{2} \mathrm{O}_{3}$ ), estimated by the Scherrer equation, are very small accordingly to the high-developed specific surface area (Table 2).

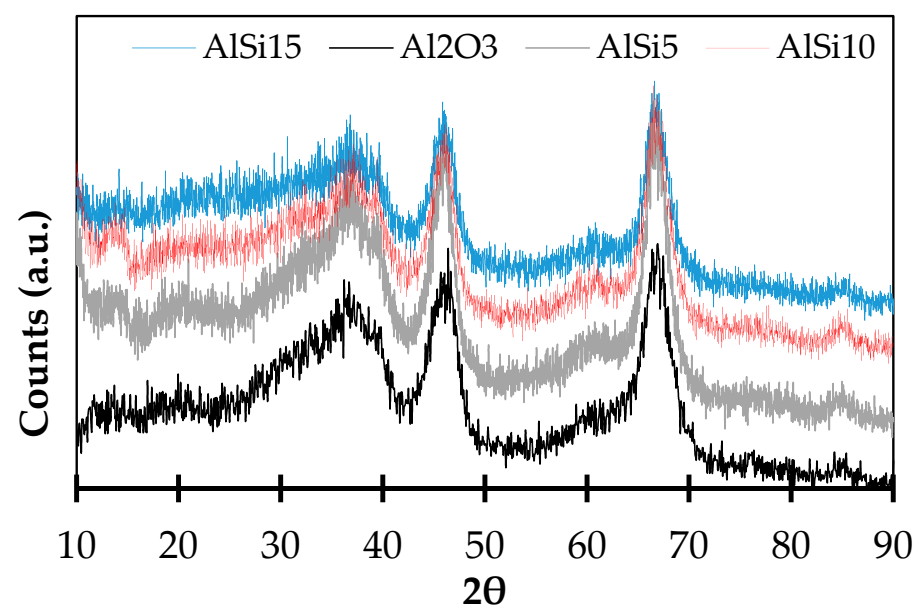

Figure 2. XRD Diffractograms of powder catalysts AlSix, where $\mathrm{x}$ is 5, 10 and $15 \mathrm{~mol} \%$ of silica.

The temperature-programmed desorption of $\mathrm{NH}_{3}$ allows quantifying the total amount of acid sites existing on the surface of the studied materials. Based on the earlier results, distinction between the weak, medium and strong acid sites can also be made by using desorption temperature. However, it is not possible to identify the nature of the acidic sites i.e., Lewis and Brønsted acid sites [43,44]. In our case, the total amount of acid sites is rising up with increasing the $\mathrm{SiO}_{2}$ loading. AlSi15 $\left(0.61 \mathrm{mmol} \mathrm{g}^{-1}\right)$ is presenting the highest amount of acidity followed by AlSi10 $\left(0.55 \mathrm{mmol} \mathrm{g}^{-1}\right)$ and AlSi5 (0.52 $\mathrm{mmol} \mathrm{g}^{-1}$ ) (calculated based on Figure 3). This result can be explained by the fact that alumina is amphoteric or slightly acidic and silica presents Brønsted acid sites [45], which leads to acidic mixed oxides.

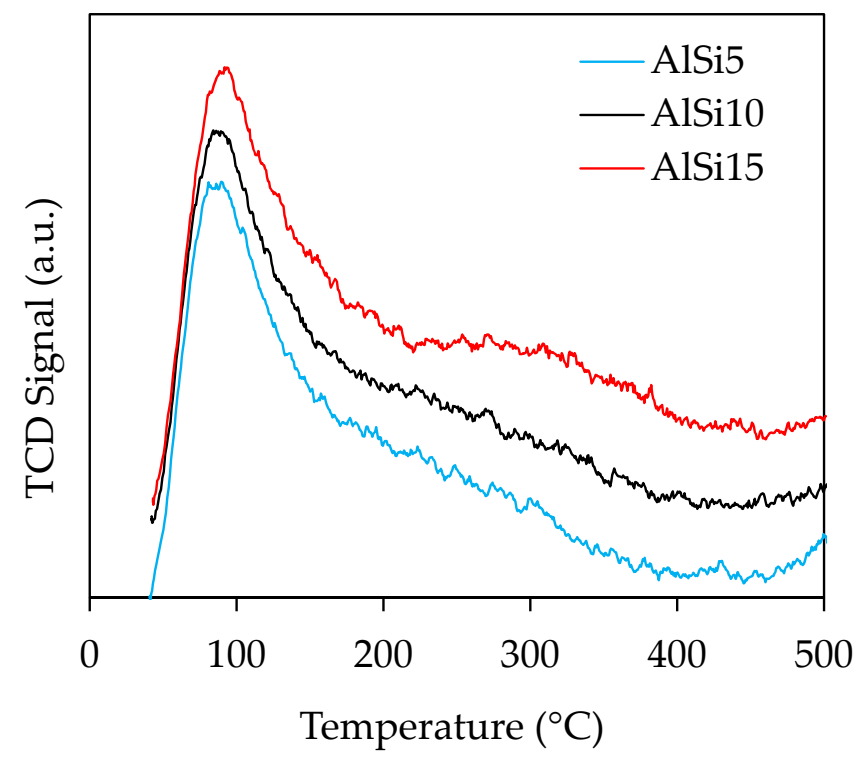

Figure 3. $\mathrm{NH}_{3}-\mathrm{TPD}$ results for powder samples AlSi5, AlSi10 and AlSi15. 


\subsection{Characterization of the Monolith Catalysts}

The geometric parameters of the studied cordierite monoliths having two different channel densities (200 and $600 \mathrm{cpsi}$ ) were determined by using the channel size (d) and the wall thickness (e) as reported by Cybulski et al. [37] (Figure 4) as follows:

$$
\begin{gathered}
\text { Number of channel per surface, } \mathrm{n}=\left(25.4 / \mathrm{d}_{\mathrm{ch}}\right)^{2} \text { [cpsi] } \\
\text { Geometric surface area: GSA }\left[\mathrm{mm}^{-1}\right]=4 \mathrm{n}\left(\mathrm{d}_{\mathrm{ch}}-\mathrm{e}_{\mathrm{ch}}\right) \\
\text { Open fraction area, OFA }=\mathrm{n}\left(\mathrm{d}_{\mathrm{ch}}-\mathrm{e}_{\mathrm{ch}}\right)^{2} \\
\text { Hydraulic diameter, } \mathrm{D}_{\mathrm{h}}[\mathrm{mm}]=4(\mathrm{OFA} / \mathrm{GSA}) \\
\text { Thermal Integrity Factor, TIF }=\mathrm{d}_{\mathrm{ch}} / \mathrm{e}_{\mathrm{ch}} \\
\text { Mechanical Integrity Factor, MIF }=\mathrm{e}_{\mathrm{ch}}{ }^{2} /\left(\mathrm{d}_{\mathrm{ch}}\left(\mathrm{d}_{\mathrm{ch}}-\mathrm{e}_{\mathrm{ch}}\right)\right)
\end{gathered}
$$

The geometric parameters for the used cordierite monoliths are summarized in Table 3.
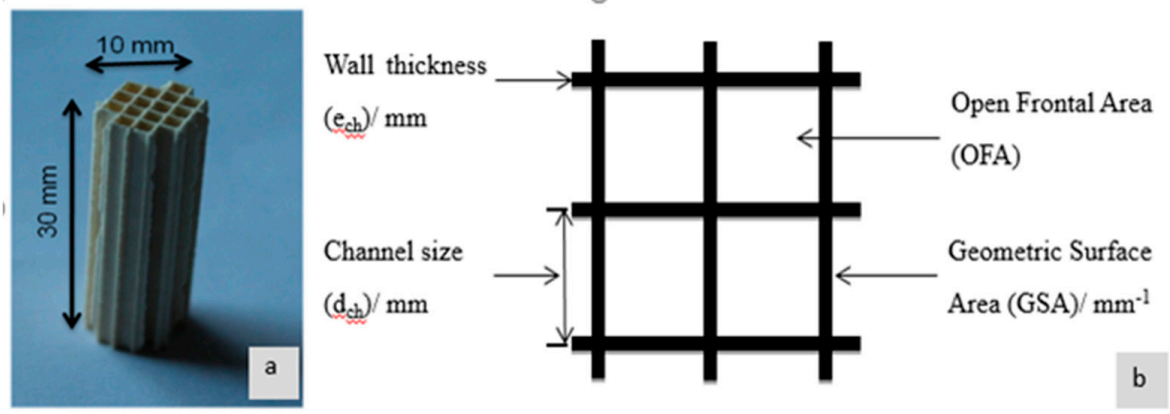

Figure 4. (a) Photography of a monolith used in this study and (b) schematic representation of the main geometrical parameters of the ceramic monoliths.

Table 3. Geometrical parameters of the used ceramic monoliths.

\begin{tabular}{ccccccccc}
\hline $\begin{array}{c}\text { Monoliths Channel } \\
\text { Density * (cpsi) }\end{array}$ & $\mathbf{d}_{\mathbf{c h}} / \mathbf{m m}$ & $\mathbf{e}_{\mathbf{c h} / \mathbf{m m}}$ & $\mathbf{n} / \mathbf{c p s i}$ & $\mathbf{G S A} / \mathbf{m m}^{-1}$ & OFA & $\mathbf{D}_{\mathbf{h}} / \mathbf{m m}$ & TIF & MIF \\
\hline 200 & 1.92 & 0.30 & 175 & 1.76 & 0.71 & 1.62 & 6.40 & 0.03 \\
600 & 1.03 & 0.24 & 628 & 2.97 & 0.59 & 0.79 & 4.29 & 0.07 \\
\hline \multicolumn{7}{c}{${ }^{*}$ Values of channel density given by the manufacturer; cpsi means cells per square inch. }
\end{tabular}

Earlier, Gulati [37] reported for exhaust gas abatement, that the ideal monolith should present high value of GSA, OFA, TIF and MIF and low $\mathrm{D}_{\mathrm{h}}$. The highest GSA and channel density lead to the highest conversion, a high value of OFA and large $D_{h}$ give low back pressure, and for optimal mechanical and thermal durability, the monolith requires a high value of MIF and TIF. In the current study, the 600 cpsi sample presents higher GSA, MIF and lower OFA, TIF and $D_{h}$ than the $200 \mathrm{cpsi}$ sample. Since the studied reaction is rather fast, we expect higher GSA to be beneficial for the reaction, according to Roy et al. [46].

The amount of the coated AlSix layer on the monoliths was used in calculation of the mass of the platinum precursor required to have $1 \mathrm{wt} \%$ of Pt per gram of washcoat in the final catalyst. The amount of the washcoat deposited on the monoliths reached around $10 \mathrm{wt} \%$ and $18 \mathrm{wt} \%$ for 200 and 600 cpsi samples, respectively. The monoliths are then denoted $200 \mathrm{Mx}$ and $600 \mathrm{Mx}$, where 200 and 600 represent the channel densities and $x$ is the molar amount of $\mathrm{SiO}_{2}$ to $\mathrm{Al}_{2} \mathrm{O}_{3}$.

The XRD diffractograms of the coated monoliths showed only the characteristic peaks of the cordierite substrate (ICDD 00-048-1600) and thus it is difficult to distinguish the reflections of AlSix 
washcoat. As powder samples, the $\mathrm{N}_{2}$-physisorption of all washcoated monoliths exhibit isotherms of Type IV characteristic of mesoporous material, and hysteresis Type H2. Results show that the coated monoliths present an average surface area around $30 \mathrm{~m}^{2}$ per gram of coated monolith while the $\mathrm{S}_{\mathrm{BET}}$ of uncoated monolith is only $10 \mathrm{~m}^{2} \mathrm{~g}^{-1}$, demonstrating the successful deposition of AlSix on the monolith. The specific surface areas of monolith samples, expressed per gram of washcoat, remain high-in the 200-300 $\mathrm{m}^{2} \mathrm{~g}^{-1}$ range for all AlSix monolithic samples (Table 4). The difference in specific surface area between powder and monolith samples is probably due to the heterogeneity of the washcoated layer and/or due to the fact that ceramic samples were broken before analysis, which leads to some loss of the washcoat affecting the accuracy of the measurement. The pore sizes and pore volumes expressed by gram of washcoat are close to those obtained for powder samples. These results pointed out that the textural properties of the powder are kept similar after washcoating the powder on the monolith substrate.

Table 4. Structural and textural properties of coated and uncoated monoliths (200M corresponding to the monolith treated with $\mathrm{HNO}_{3}$ ).

\begin{tabular}{|c|c|c|c|c|c|c|c|}
\hline \multirow[t]{2}{*}{ Monolith } & \multicolumn{2}{|c|}{$\mathrm{S}_{\mathrm{BET}} / \mathrm{m}^{2} \mathrm{~g}^{-1}$} & \multirow{2}{*}{$\begin{array}{l}\text { wt } \% \text { of } \\
\text { Coated Phase } \\
\text { on the } \\
\text { Monolith }\end{array}$} & \multicolumn{2}{|c|}{ Pore Volume $/ \mathrm{cm}^{3} \mathrm{~g}^{-1}$} & \multirow[b]{2}{*}{$\begin{array}{l}\text { Pore Size } \\
\text { /nm }\end{array}$} & \multirow[b]{2}{*}{$\begin{array}{l}\text { Phase } \\
\text { (XRD) }\end{array}$} \\
\hline & $\begin{array}{l}\text { Per g of } \\
\text { Monolith }\end{array}$ & $\begin{array}{c}\text { Per g of } \\
\text { Coated } \\
\text { Phase }\end{array}$ & & $\begin{array}{l}\text { Per g of } \\
\text { Monolith }\end{array}$ & $\begin{array}{l}\text { Perg of } \\
\text { Coated } \\
\text { PHASE }\end{array}$ & & \\
\hline $200 \mathrm{M}$ & 10 & - & - & 0.01 & - & 3 & Cordierite \\
\hline 200M5 & 35 & 290 & 12 & 0.04 & 0.34 & 5 & Cordierite \\
\hline 200M10 & 30 & 215 & 14 & 0.03 & 0.22 & 4 & Cordierite \\
\hline 200M15 & 30 & 230 & 13 & 0.03 & 0.23 & 4 & Cordierite \\
\hline
\end{tabular}

The FESEM images of a virgin (Figure 5a) and coated monoliths (Figure 5b) show clearly that the washcoating of AlSix on the surface of the ceramics was successful. The layer deposited, having around $4 \mu \mathrm{m}$ of thickness, is relatively homogeneous with small cracks probably due to the viscosity of the sol used for the washcoating and the thermal treatments. However, by comparing the semi-quantitative EDS analysis of the uncoated and coated monoliths, the results gathered in Table 5 and Figure $5 \mathrm{~d}$ evidenced the presence of a very low amount of magnesium on the surface of washcoated monolith, which proves the major presence of AlSi10 covering all the cordierite surface.

Table 5. Elemental composition of uncoated and 200M10 samples determined by EDS analysis.

\begin{tabular}{cccccc}
\hline Monoliths & Al (wt \%) & Si (wt \%) & O (wt \%) & Mg (wt \%) & Total \\
\hline Substrate & 18 & 25 & 49 & 8 & 100 \\
Coated substrate & 42 & 11 & 46 & 1 & 100 \\
\hline
\end{tabular}
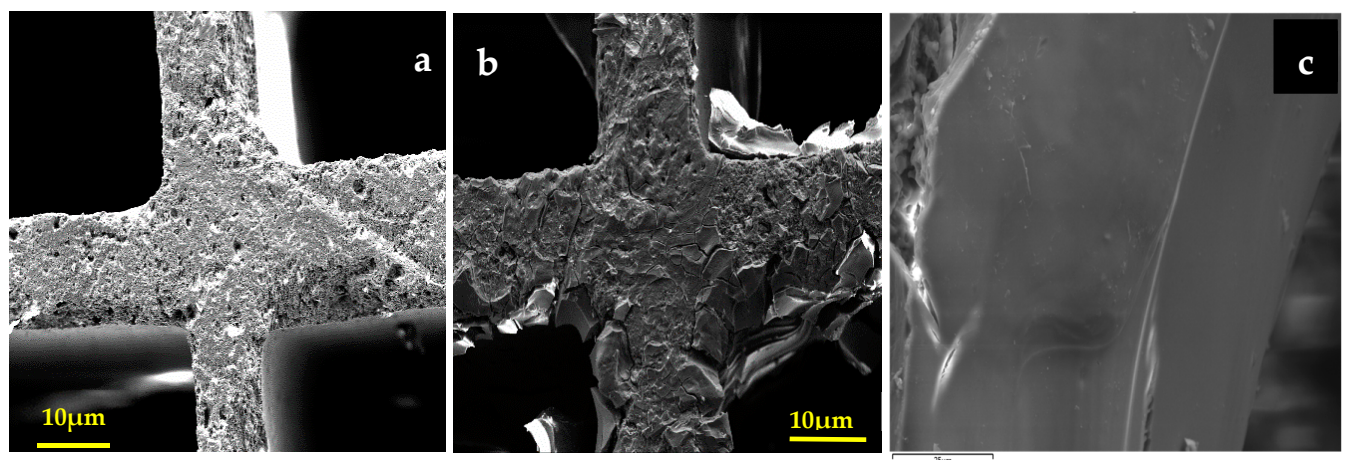

Figure 5. Cont. 


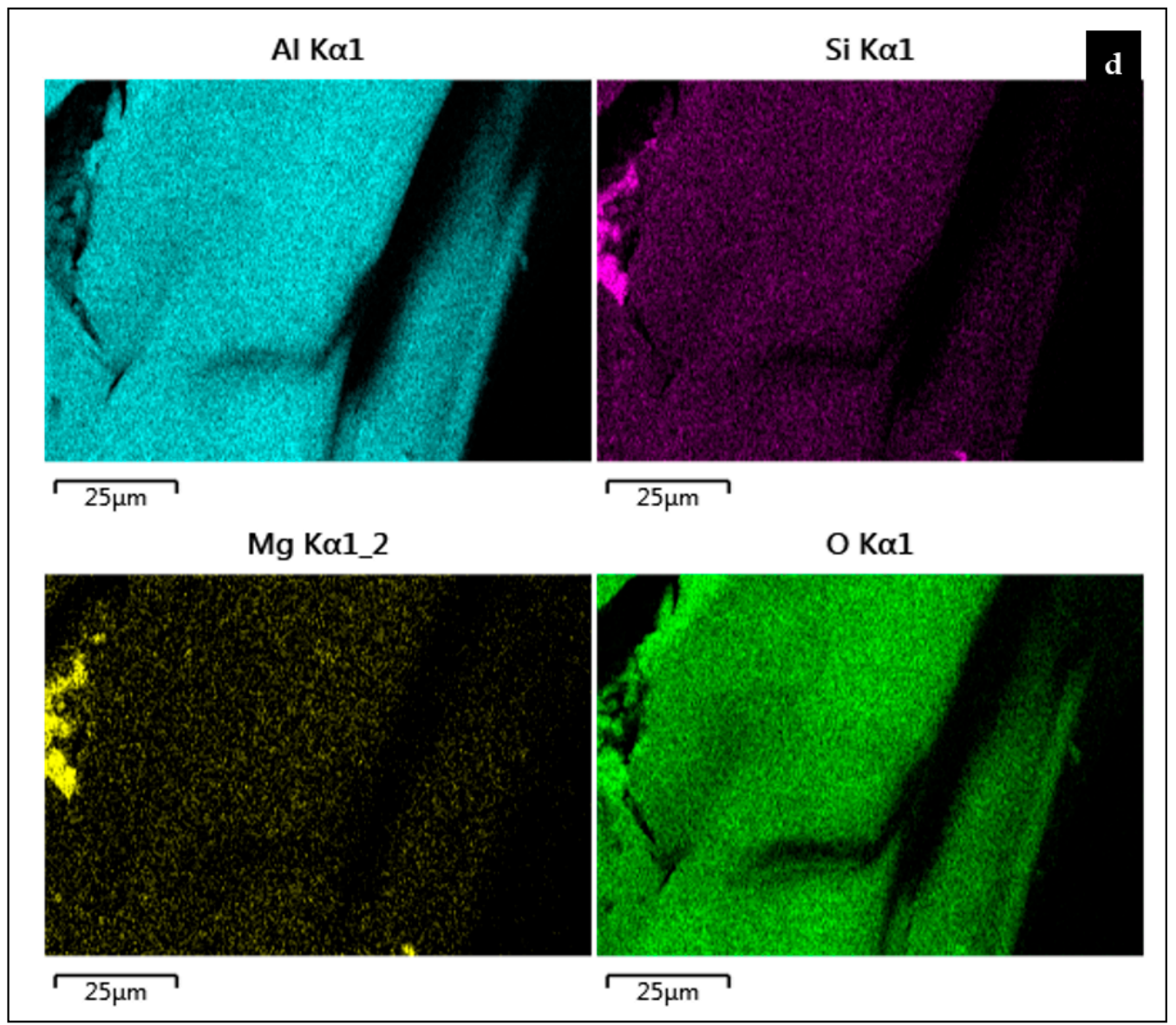

Figure 5. FESEM images taken from the substrate (a) and washcoated monoliths (b) and position of EDS area and (d) is the EDS mapping image of coated monolith (c).

\subsection{Activity Tests}

The activity test results are presented only for the monolith catalysts. The DCM light-off curves (conversion vs. temperature) for the monolith catalysts having $200 \mathrm{cpsi}$ are shown in Figure 6. As it can be seen, there are no large differences between the monoliths, when DCM conversion is considered. The conversion of more than $80 \%$ over all the monolith catalysts is reached at $500{ }^{\circ} \mathrm{C}$. The exact values for conversion at $500{ }^{\circ} \mathrm{C}$ and $\mathrm{T}_{50}$ are given in Table 6 . The increase in the loading of silica, nor the addition of $1 \mathrm{wt} \%$ of $\mathrm{Pt}$, do not seem to improve the DCM conversion significantly. 200M10 was able to oxidize slightly more DCM than the other samples. Since the different samples give very similar results in terms of DCM conversion, hereafter, $\mathrm{HCl}$ and by-products are discussed to evaluate the catalysts performance more clearly.

Figure 7 shows the $\mathrm{HCl}$ yields reached over the catalysts Pt200Mx and 200Mx during the DCM oxidation. $\mathrm{HCl}$ is one of the wanted final products, and high $\mathrm{HCl}$ formation gives an indication on catalyst stability ( $\mathrm{Cl}$ does not remain on the catalyst surface). In addition, water vapor was added to feed mixture to improve $\mathrm{HCl}$ formation instead of formation of $\mathrm{Cl}_{2}$ according to Deacon reaction [34,35]. In this case, the differences are slightly more visible than in the case of DCM conversion. The highest $\mathrm{HCl}$ yield was observed for Pt200M10 (75\%) and the lowest for Pt200M5 with 50\% yield. The addition of $\mathrm{Pt}$ improved the $\mathrm{HCl}$ formation for all, except for 200M5 catalysts. This small difference might be due to differences in Pt loadings on the monoliths. Unfortunately, we were not able to quantify the $\mathrm{Pt}$ content on the monolith reliably to verify this assumption. 


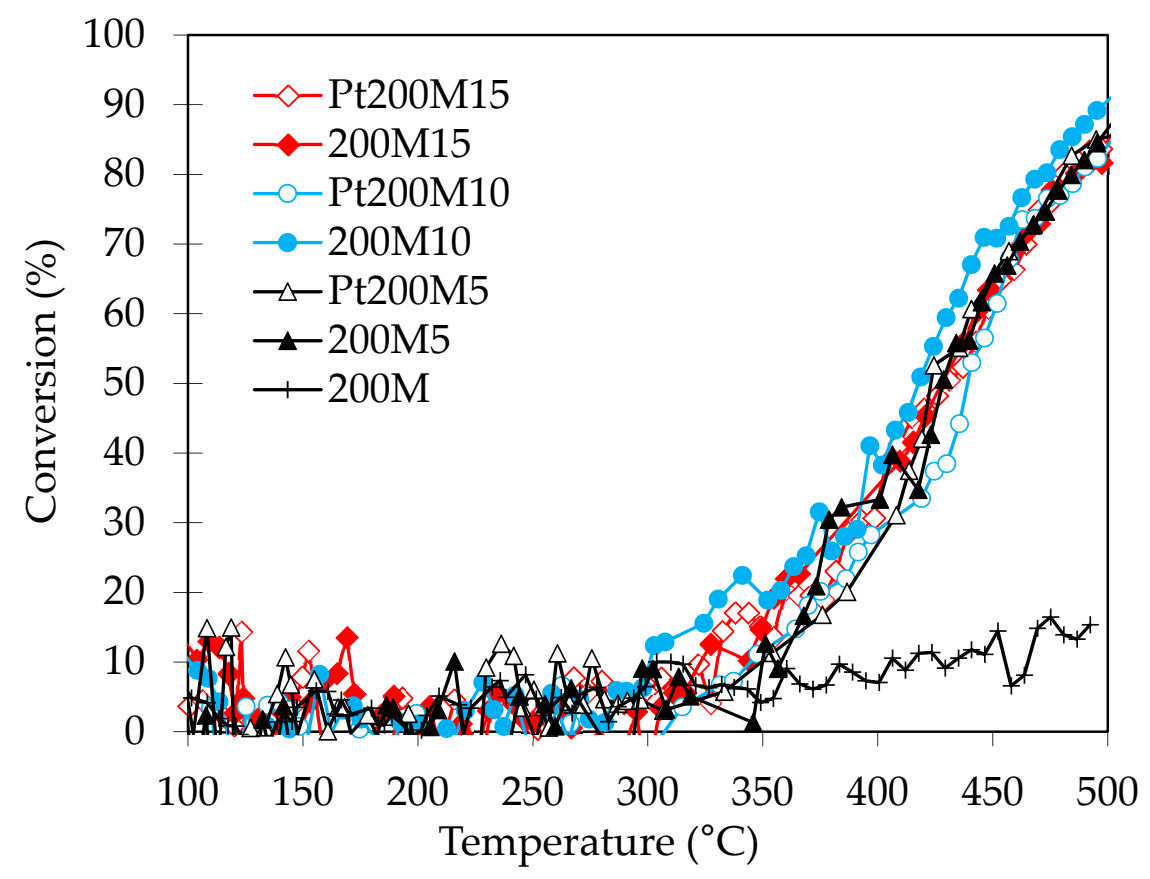

Figure 6. Light-off curves for DCM oxidation over monolith catalysts with 200 cpsi. (Experimental conditions: DCM 500 ppm, GHSV 30,556 h-1 $\left.\left(1.2 \mathrm{~L} \mathrm{~min}^{-1}\right), \mathrm{H}_{2} \mathrm{O} 1.5 \mathrm{vol} \%\right)$ In the Figure 200M is the cordierite substrate alone and $200 \mathrm{Mx}(\mathrm{x}=5,10,15)$ is the coated monolith where $\mathrm{x}$ is the loading of silica on alumina.

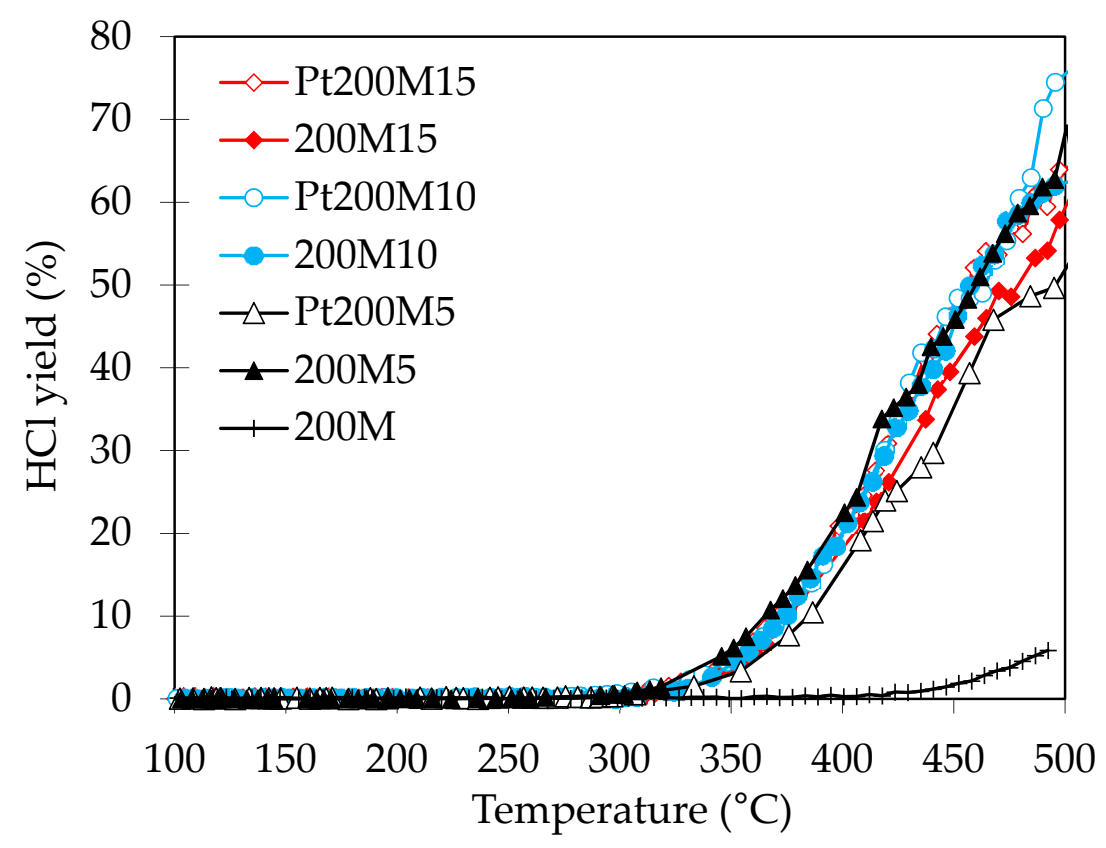

Figure 7. $\mathrm{HCl}$ yield over 200Mx monoliths. The same experimental conditions were used as in Figure 6.

Figure 8 presents the major byproducts formed over the coated monoliths during DCM oxidation. These are carbon monoxide $(\mathrm{CO})$, methyl chloride $\left(\mathrm{CH}_{3} \mathrm{Cl}\right)$ and formaldehyde $\left(\mathrm{CH}_{2} \mathrm{O}\right)$. The other chlorinated byproducts, such as tetrachloroethylene $\left(\mathrm{C}_{2} \mathrm{Cl}_{4}\right)$, chloroform $\left(\mathrm{CHCl}_{3}\right)$ and trichloroethylene $\left(\mathrm{C}_{2} \mathrm{HCl}_{3}\right)$ were present in trace amounts reaching maximum of $5 \mathrm{ppm}$ (the detection limit of the used analysis was $\sim 2 \mathrm{ppm}$ ). CO was observed to be the major byproduct over washcoated monoliths (without Pt). After Pt impregnation, due to improved oxidation of DCM, the CO amount was decreased 
to an insignificant level in accordance to its transformation into $\mathrm{CO}_{2}$. The amounts of $\mathrm{CH}_{3} \mathrm{Cl}$ and $\mathrm{CH}_{2} \mathrm{O}$ were also diminished after $\mathrm{Pt}$ impregnation. These results are in agreement with our previous results related to DCM oxidation over a Pt catalyst impregnated on simple oxides [35]. The comparison between different catalysts to each other (based on Figure 8) revealed that the $\mathrm{CH}_{3} \mathrm{Cl}$ formation was highest over 200M5 $\left(\sim 470{ }^{\circ} \mathrm{C}\right)$ (Figure 8a) followed by 200M15 $\left(\sim 500{ }^{\circ} \mathrm{C}\right)$ (Figure 8c) and 200M10 $\left(\sim 480^{\circ} \mathrm{C}\right)$ (Figure $\left.8 \mathrm{~b}\right)$. After impregnation of $\mathrm{Pt}$, the decrease in $\mathrm{CH}_{3} \mathrm{Cl}$ formation was relatively more significant than that of $\mathrm{CH}_{2} \mathrm{O}$. According to earlier studies, $\mathrm{CH}_{3} \mathrm{Cl}$ is formed on Lewis acid sites while $\mathrm{CH}_{2} \mathrm{O}$ is formed on Brønsted sites [18,29,30,35]. If this is true, after Pt impregnation, the availability of Lewis acid sites might have been affected.
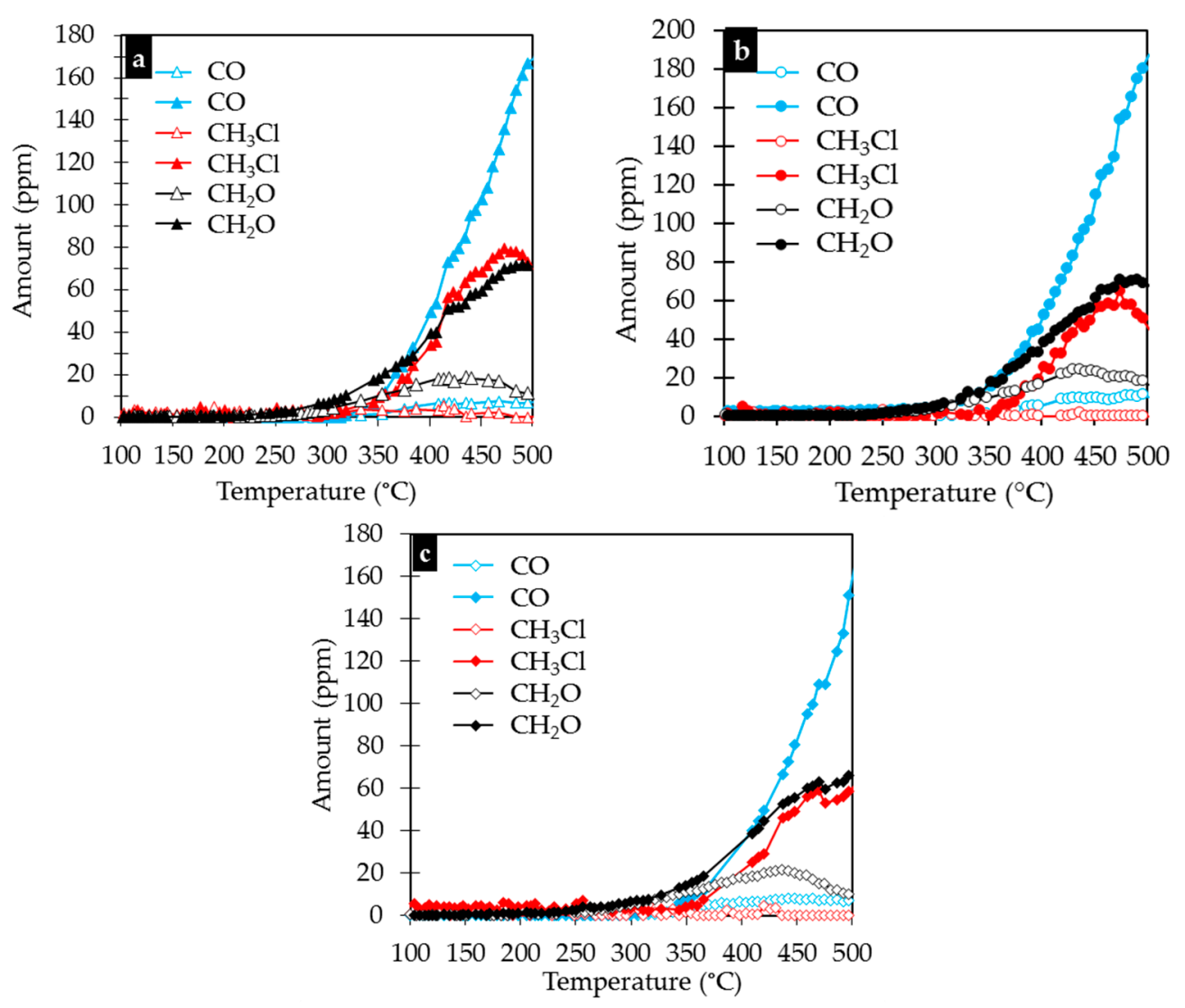

Figure 8. Byproduct formation over coated monoliths (a) 200M5; (b) 200M10 and (c) 200M15 based catalysts, open symbols are for Pt-containing $200 \mathrm{Mx}$ and closed symbols are for 200Mx. The same experimental conditions were used as in Figure 6.

The results obtained are in agreement with previous studies, where the oxidation of DCM was suggested to proceed via two steps $[10,16,28-30,35]$. The first reaction step is proposed to occur on the support in the presence of steam and it results in the formation of formaldehyde $\left(\mathrm{CH}_{2} \mathrm{O}\right)$ and methyl chloride $\left(\mathrm{CH}_{3} \mathrm{Cl}\right)$ depending on the type of the acid sites present on the surface, as described before. In our study, we observed the formation of the same major byproducts. The second step of the reaction is then the conversion of the formed byproducts to $\mathrm{CO}_{2}, \mathrm{H}_{2} \mathrm{O}$ and $\mathrm{HCl}$ on the Pt sites. In our case, the same observation was evidenced. Furthermore, before Pt impregnation, an increase in the amount of silica on alumina decreases slightly the total amount of formed byproducts and improves the $\mathrm{HCl}$ yield. This may have a relation to increasing acidity while increasing the silica loading. Table 6 summarizes the conversions of DCM, yields of $\mathrm{HCl}$, amounts of byproducts formed at $500{ }^{\circ} \mathrm{C}$ and at $\mathrm{T}_{50}$ of DCM oxidation. In the view of DCM conversion and $\mathrm{HCl}$ yield, the Pt200M10 catalyst showed 
slightly better performance than the other catalysts, and thus it was used for comparison with a monolith having cell density of 600 cpsi.

Table 6. DCM conversions, $\mathrm{HCl}$ yield and byproduct amount over different 200Mx based catalysts.

\begin{tabular}{|c|c|c|c|c|c|c|c|}
\hline & & 200M5 & Pt200M5 & 200M10 & Pt200M10 & 200M15 & Pt200M15 \\
\hline \multicolumn{2}{|c|}{ Mass of Catalysts (g) } & 0.149 & 0.157 & 0.138 & 0.120 & 0.165 & 0.185 \\
\hline \multicolumn{2}{|c|}{$\mathrm{T}_{50}$ of DCM Conversion $\left({ }^{\circ} \mathrm{C}\right)$} & 430 & 425 & 420 & 440 & 430 & 430 \\
\hline \multicolumn{2}{|c|}{ DCM Conversion at $500^{\circ} \mathrm{C}$} & 85 & 85 & 90 & 85 & 80 & 85 \\
\hline \multirow[b]{2}{*}{$\% \mathrm{HCl}$} & $\mathrm{T}_{50}\left({ }^{\circ} \mathrm{C}\right)$ & 35 & 25 & 30 & 40 & 30 & 35 \\
\hline & $500{ }^{\circ} \mathrm{C}$ & 70 & 50 & 60 & 75 & 60 & 65 \\
\hline \multirow{2}{*}{$\mathrm{CO}(\mathrm{ppm})$} & $\mathrm{T}_{50}\left({ }^{\circ} \mathrm{C}\right)$ & 80 & 5 & 70 & 10 & 60 & 10 \\
\hline & $500{ }^{\circ} \mathrm{C}$ & 170 & 5 & 185 & 10 & 160 & 5 \\
\hline \multirow{2}{*}{$\mathrm{CH}_{2} \mathrm{O}(\mathrm{ppm})$} & $\mathrm{T}_{50}\left({ }^{\circ} \mathrm{C}\right)$ & 50 & 15 & 45 & 20 & 50 & 20 \\
\hline & $500^{\circ} \mathrm{C}$ & 70 & 10 & 70 & 15 & 70 & 10 \\
\hline \multirow{2}{*}{$\mathrm{CH}_{3} \mathrm{Cl}(\mathrm{ppm})$} & $\mathrm{T}_{50}\left({ }^{\circ} \mathrm{C}\right)$ & 60 & 5 & 30 & 0 & 35 & 5 \\
\hline & $500^{\circ} \mathrm{C}$ & 70 & 0 & 45 & 0 & 60 & 5 \\
\hline $\begin{array}{l}\text { Formed } \\
\text { Byproducts } \\
\text { (ppm) }\end{array}$ & $500^{\circ} \mathrm{C}$ & 310 & 15 & 300 & 25 & 290 & 20 \\
\hline
\end{tabular}

Figure 9 displays the light-off curves of DCM over both monoliths with 200 cpsi (200M10) and with 600 cpsi (600M10) coated with AlSi10 before and after the Pt impregnation. As can be seen, the $600 \mathrm{M} 10$ catalysts are able to convert DCM more efficiently than 200M10. This is due to a higher geometric surface area of 600M10 than that of 200M10, which allows better contact of DCM with active sites. However, it is good to note, that 600M10 has slightly more washcoat (in grams) on the monolith than 200M10. After impregnation of Pt, a slight decrease in DCM conversion was observed over both types of monoliths. This may be due to the modification of the surface of the washcoat or quality of washcoat after Pt impregnation.

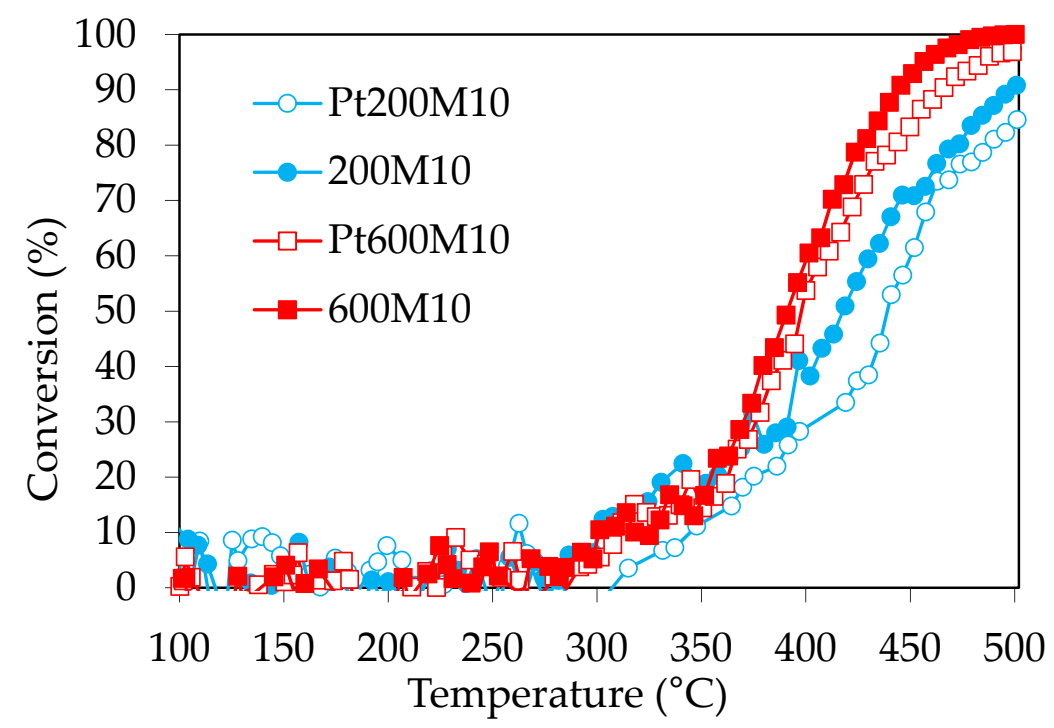

Figure 9. Comparison of DCM oxidation between 200M and M600 monoliths coated with AlSi10, with (open symbols) or without (closed symbols) Pt. 200M and 600M are meaning monoliths with 200 and 600 cpsi, respectively. The same experimental conditions were used as in Figure 6. 
$\mathrm{HCl}$ production (Figure 10) over monoliths with $600 \mathrm{cpsi}$ is higher than over monoliths with 200 cpsi. Pt addition has no significant effect on the $\mathrm{HCl}$ formation, except at $500{ }^{\circ} \mathrm{C}$ for Pt200M10. It is clear that the increase in channel density (high GSA) also increases the DCM conversion and thus $\mathrm{HCl}$ yield.

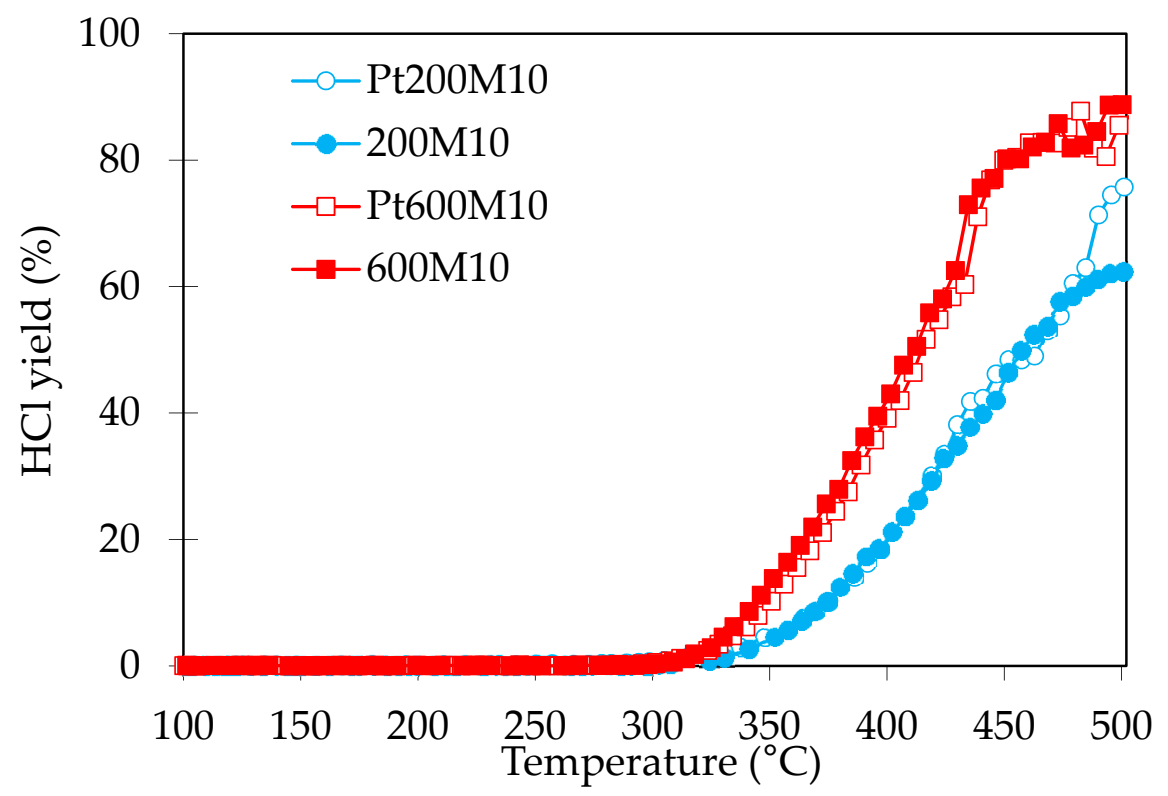

Figure 10. Comparison of $\mathrm{HCl}$ yield between coated monoliths (200M and 600M10) with AlSi10 in presence of $\mathrm{Pt}$ (open symbols) or not (closed symbols). The same experimental conditions were used as in Figure 6.

The same remarks than for the monoliths with 200 cpsi can be made for the monoliths with $600 \mathrm{cpsi}$ in terms of by-products formation. The main by-products are $\mathrm{CO}, \mathrm{CH}_{2} \mathrm{O}$ and $\mathrm{CH}_{3} \mathrm{Cl}$. The results shown in Figure 11a illustrate that the formation of by-products over coated monoliths is significantly decreased and/or disappeared after the impregnation of Pt. The comparison of the yields of by-products over both the coated monoliths 200M10 and 600M10 are shown in Figure 11b. It is clear that $600 \mathrm{M} 10$ gives higher amount of by-products than 200M10 since it gives also the higher conversion of DCM at corresponding temperature. At temperature superior to $400{ }^{\circ} \mathrm{C}$, the $\mathrm{CH}_{2} \mathrm{O}$ formation was higher over 200M10 than 600M10, which is due to more complete oxidation of DCM at lower temperature range with 600M10. As it can be seen from Figure 11, formation of $\mathrm{CH}_{3} \mathrm{Cl}$ and $\mathrm{CH}_{2} \mathrm{O}$ have already reached the maxima at around 455 and $440{ }^{\circ} \mathrm{C}$, respectively, and started to react further towards complete oxidation products. After impregnation of $\mathrm{Pt}$, the amount of by-products was lower over Pt600M10 compared to the Pt200M10 catalyst (figure not shown).

In general, DCM conversion and $\mathrm{HCl}$ yields were higher over the $600 \mathrm{M} 10$ samples than over $200 \mathrm{M} 10$ at $500{ }^{\circ} \mathrm{C}$. However, if the production of $\mathrm{HCl}, \mathrm{CO}, \mathrm{CH}_{2} \mathrm{O}$ and $\mathrm{CH}_{3} \mathrm{Cl}$ at $\mathrm{T}_{50}$ and at $500{ }^{\circ} \mathrm{C}$ are considered (Table 7), 200M10 produces less by-products than 600M10 (except for $\mathrm{CH}_{2} \mathrm{O}$ over Pt200M10 at $\mathrm{T}_{50}$ and $200 \mathrm{M} 10$ at $500{ }^{\circ} \mathrm{C}$ ). As earlier, Pt improved the total oxidation, and the by-product formation was lowest over Pt600M10. The by-product amounts were decreased by 90 and $95 \%$ after impregnation over $200 \mathrm{M} 10$ and $600 \mathrm{M} 10$, respectively. The $600 \mathrm{M} 10$ catalyst, in general, has better performance than that of 200M10. A part of the better performance might be due to higher real mass of washcoat on 600Mx, however, similar higher mass was calculated for Pt200M15 that did not improve its performance significantly (See Table 6 before). 

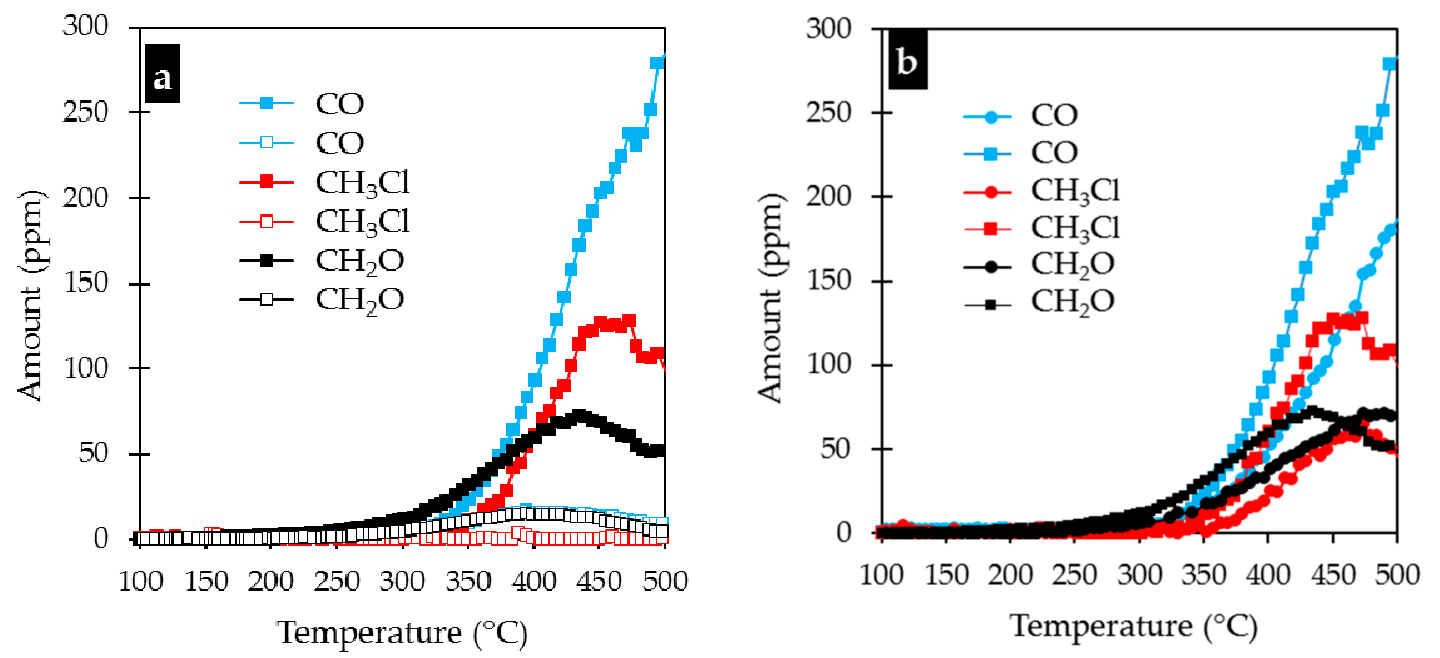

Figure 11. By-products formation (a) over 600M10 (Open symbols are used for Pt-containing 600M10 and closed are symbols for 600M10) and (b) comparison between 200M10 (•) and 600M10 ( $\mathbf{\square})$. The same experimental conditions were used as in Figure 6.

Table 7. DCM conversion, $\mathrm{HCl}$ and byproduct yields over different catalysts zPtyM10, where $\mathrm{z}$ is 0 or $1 \mathrm{wt} \%$ of Pt and y is the density of monolith (200 and $600 \mathrm{cpsi}$ ).

\begin{tabular}{cccccc}
\hline & 200M10 & Pt200M10 & 600M10 & Pt600M10 \\
\hline Mass of Catalysts (g) & 0.138 & 0.120 & 0.19 & 0.1899 \\
\hline $\mathrm{T}_{50}$ of DCM Conversion & 420 & 440 & 390 & 400 \\
\hline DCM Conversion at $500{ }^{\circ} \mathrm{C}$ & 90 & 85 & 100 & 95 \\
\hline$\% \mathrm{HCl}$ & $\mathrm{T}_{50}$ & 30 & 40 & 35 & 40 \\
& $500^{\circ} \mathrm{C}$ & 60 & 75 & 90 & 85 \\
\hline \multirow{2}{*}{$\mathrm{CO}(\mathrm{ppm})$} & $\mathrm{T}_{50}$ & 70 & 10 & 75 & 15 \\
& $500^{\circ} \mathrm{C}$ & 185 & 10 & 285 & 10 \\
\hline \multirow{2}{*}{$\mathrm{CH} \mathrm{H}_{2} \mathrm{O}(\mathrm{ppm})$} & $\mathrm{T}_{50}$ & 45 & 20 & 55 & 15 \\
\hline \multirow{2}{*}{$\mathrm{CH}{ }_{3} \mathrm{Cl}(\mathrm{ppm})$} & $500^{\circ} \mathrm{C}$ & 70 & 15 & 50 & 5 \\
\hline Formed byproducts $(\mathrm{ppm})$ & $500{ }^{\circ} \mathrm{C}$ & 300 & 0 & 45 & 0 \\
\hline
\end{tabular}

Finally, according to our results and based on the values presented in Table 3, the key parameters for high performance of monoliths, in our experimental conditions, are low values of OFA, $\mathrm{D}_{\mathrm{h}}$ and TIF in addition to high values of MIF and GSA. These were achieved with the substrate having cell density of 600 cpsi.

\section{Materials and Methods}

\subsection{Preparation of $\left(\mathrm{Al}_{2} \mathrm{O}_{3}\right)_{1-x}\left(\mathrm{SiO}_{2}\right)_{x}$}

The $\left(\mathrm{Al}_{2} \mathrm{O}_{3}\right)_{1-\mathrm{x}}\left(\mathrm{SiO}_{2}\right)_{\mathrm{x}}$ samples were prepared by modifying the procedure described by Nijhas et al. [47]. The starting materials were Disperal P2 (AlOOH, $260 \mathrm{~m}^{2} \mathrm{~g}^{-1}$, Sasol Germany, Hamburg, Germany), urea $\left(\mathrm{NH}_{2} \mathrm{CONH}_{2}\right.$, Sigma Aldrich, St. Louis, MO, USA), $0.3 \mathrm{M}$ of nitric acid $\left(\mathrm{HNO}_{3}\right.$, Merck, Kenilworth, NJ, USA) with the molar ratio of 2/1/5, and tetraethylorthosilicate $\left(\mathrm{Si}\left(\mathrm{OCH}_{2} \mathrm{CH}_{3}\right)_{4}\right.$, TEOS, Sigma Aldrich St. Louis, MO, USA). The amount of urea was dissolved step by step in $\mathrm{HNO}_{3}(0.3 \mathrm{M})$ under high-speed stirring $(1600 \mathrm{rpm})$ at room temperature. After that, the needed 
amount of TEOS to obtain the desired amount of $\mathrm{SiO}_{2}$ was added to the solution followed by the continuous addition of a corresponding amount of Disperal P2 in small quantities. A white viscous sol was obtained after $2 \mathrm{~h}$ of vigorous stirring. The prepared $\left(\left(\mathrm{Al}_{2} \mathrm{O}_{3}\right)_{1-\mathrm{x}}\left(\mathrm{SiO}_{2}\right)_{\mathrm{x}}\right)$ samples were denoted as AlSix where $x$ is the molar ratio of silica added to alumina. The molar ratio of silica used was 5,10 and $15 \%$. One part of the obtained sol was used in washcoating of the monoliths and the other part of the same sol was saved in a powder form for analysis purposes.

\subsection{Honeycomb Monoliths}

The honeycomb monoliths, used in this study, were cordierites with the chemical formula of $\mathrm{Mg}_{2} \mathrm{~A}_{14} \mathrm{Si}_{5} \mathrm{O}_{18}\left(14 \% \mathrm{MgO}, 35 \% \mathrm{Al}_{2} \mathrm{O}_{3}\right.$ and $\left.51 \% \mathrm{SiO}_{2}\right)$. They were provided by Corning Company (Germany). In this study, we used a cylindrical monolith with two different channel densities (200 and $600 \mathrm{cpsi}$ ). The monoliths used had the diameter of $10 \mathrm{~mm}$ and length of $30 \mathrm{~mm}$ selected based on the reactor dimensions.

To clean and eliminate the impurities from the channels, the monoliths were immersed in concentrated nitric acid (65\%) for $1 \mathrm{~h}$. After that, they were washed carefully with ultrapure water followed by drying in a ventilated oven at $100{ }^{\circ} \mathrm{C}$. The dried monoliths were calcined at $300{ }^{\circ} \mathrm{C}$ for $1 \mathrm{~h}$ with $1{ }^{\circ} \mathrm{C} \mathrm{min}^{-1}$ as the rate for the temperature to minimize the thermal stress during the treatment. This treatment of monoliths aims at increasing slightly the surface area of monoliths and also to decrease the thermal expansion coefficient (CTE) [40,48]. These uncoated monoliths are called as substrates.

The pre-treated substrates were washcoated with a viscous sol of AlSix (preparation described before) during $1 \mathrm{~h}$. Afterwards, the washcoated monoliths were flushed carefully with a low flow of $\mathrm{N}_{2}$ to remove the excess of gel from the surface and the channels of monoliths. Then, the monoliths were let to mature at room temperature overnight.

After maturation, the powders and washcoated monoliths were calcined at $120^{\circ} \mathrm{C}$ for $1 \mathrm{~h}$ and then at $500{ }^{\circ} \mathrm{C}$ for $2 \mathrm{~h}$ with $1{ }^{\circ} \mathrm{C} \mathrm{min}^{-1}$ temperature rise. This thermal profile was used to avoid cracks in the coated phase on the monoliths. The calcined and washcoated monoliths are denoted with yMx where $y$ is the channel density (200 or 600) and $x$ is the silica loading.

\subsection{Deposition of the Active Phase}

The target amount of active phase was $1 \mathrm{wt} \%$ of Pt per $1 \mathrm{~g}$ of washcoat mass (AlSix) on the monoliths. The hexachloroplatinic acid $\left(\mathrm{H}_{2} \mathrm{PtCl}_{6} \cdot \mathrm{xH}_{2} \mathrm{O}\right.$, Alfa Aesar, 99.9\%, Ward Hill, MA, USA) was used as the precursor in this step. Firstly, the corresponding mass of hexachloroplatinic acid to achieve the target composition was dissolved in a minimum amount of distilled water. Afterwards, the washcoated and calcined monoliths were immersed in the solution of the precursor of Pt and left under mechanical stirring overnight. Finally, the excess of solvent was evaporated on a sand bath at $60{ }^{\circ} \mathrm{C}$.

The Pt-impregnated monolith catalysts (denoted by PtyMx, y is the channel density (200 or 600) and $x$ is the amount of silica added to alumina) were calcined at $500{ }^{\circ} \mathrm{C}$ for $2 \mathrm{~h}$. After calcination, the catalysts were reduced under a hydrogen flow diluted in nitrogen $\left(60 \mathrm{~mL} \cdot \mathrm{min}^{-1} \mathrm{of} \mathrm{H}_{2}\right.$ and $100 \mathrm{~mL} \cdot \mathrm{min}^{-1}$ of $\mathrm{N}_{2}$ ) at $250{ }^{\circ} \mathrm{C}$ for $1 \mathrm{~h}$ and then at $500{ }^{\circ} \mathrm{C}$ for $2 \mathrm{~h}$. The temperature rate during calcination and reduction steps was $5^{\circ} \mathrm{C} \mathrm{min}^{-1}$.

\subsection{Characterisation of the Powder and Monolith Catalysts}

The X-ray diffraction data of the powder and coated monolith supports were collected using a SIEMENS D5000 XRD diffractometer (SIEMENS, Munich, Germany), as explained in [26], using Cu radiation with a wavelength of $\lambda_{\mathrm{Cu}}=0.15406 \mathrm{~nm}$ and the samples were scanned in a range of $2 \theta$ from $5^{\circ}$ to $90^{\circ}$ with the step size of $0.04^{\circ}$ and step time of $2 \mathrm{~s}$. The diffraction patterns obtained were compared with the library data from JCPDS. Data handling was carried out using the software package HighScore. 
Specific surface areas and pore volumes for the prepared powder and monolith catalysts were determined by nitrogen adsorption-desorption isotherms at $-196{ }^{\circ} \mathrm{C}$, using an ASAP 2020 instrument (Micrometrics, Norcross, GA, USA). The surface area was calculated using the BET equation and pore size distribution was determined by using the $\mathrm{BJH}$ method. Prior to adsorption experiments, the samples were degassed under a vacuum at $350{ }^{\circ} \mathrm{C}$ for $2 \mathrm{~h}$.

XRF analyses were done for AlSix powders by a PANalytical Axios-MAX apparatus (PANalytical, Almelo, The Netherlands) equipped with a rhodium anode as a standard. In order to enhance sensitivity, the power was fixed at $3 \mathrm{~kW}(60 \mathrm{kV}, 50 \mathrm{~mA})$. Prior to the analysis, the samples were diluted in X-ray flux 66/34 (Lithium Tetraborate 66\%/Lithium Metaborate 34\%, PANalytical) followed by melting this mixture at $1150{ }^{\circ} \mathrm{C}$ (PANalytical-Eagon 2) to obtain a glass disc.

The total acidity measurements of the powder-form catalysts were performed using the temperature programmed desorption of ammonia $\left(\mathrm{NH}_{3}-\mathrm{TPD}\right)$ by an AutoChem II 2920 (Micromeritics, Norcross, GA, USA) device. Prior to analysis, the sample (about $110 \mathrm{mg}$ ) was pre-treated with $\mathrm{He}$ at $500{ }^{\circ} \mathrm{C}$. After pre-treatment, adsorption of $15 \% \mathrm{NH}_{3}$ in $\mathrm{He}$ is done at room temperature for $60 \mathrm{~min}$ and followed by flushing with He for $30 \mathrm{~min}$ to eliminate the physisorbed ammonia [43]. The $\mathrm{NH}_{3}$ desorption was carried out from RT to $500{ }^{\circ} \mathrm{C}\left(5^{\circ} \mathrm{C} \mathrm{min}-1\right)$ for the powder-form AlSix. The concentration of desorbed $\mathrm{NH}_{3}$ was analysed by a TCD detector. The total acidity of samples was determined by integration of the area between $50-500{ }^{\circ} \mathrm{C}$ by AutoChem software.

The FESEM images for monoliths were obtained by a Field Emission Scanning Electron Microscope ZEISS ULTRA PLUS (ZEISS, Oberkochen, Germany) equipped with an Energy-Dispersive X-ray Spectrometer (EDS) at an accelerating voltage of $15.0 \mathrm{kV}$. Prior taking images, the monoliths were cut to fit in the FESEM chamber and carbonized. This analysis was done to verify the morphology of the coated phase and its composition.

\subsection{Catalytic Oxidation of Dichloromethane}

DCM oxidation experiments were carried out in a fixed-bed continuous flow reactor operating under atmospheric pressure explained in detail in references [26,49]. The gas analysis during the experiments was carried out with the Gasmet DX-4000N FTIR analyser (Gasmet Technologies, Helsinki, Finland).

The DCM (supplied by Sigma Aldrich; purity 99.8\%, St. Louis, MO, USA) concentration used during the experiments was $500 \mathrm{ppm}$. In all the activity tests performed, $1.5 \mathrm{vol} \%$ of water was used to ensure the sufficient selectivity towards $\mathrm{HCl}[8,20,50]$. The flow of the reaction mixture (DCM in air) was set to be $1.02 \mathrm{~L} \cdot \mathrm{min}^{-1}$ in all the experiments.

The gas hourly space velocity (GHSV) over the monoliths used in this study was about $30500 \mathrm{~h}^{-1}$. This value is very close to the industrially used GHSV in VOC treatment [51]. The temperature range during the light-off test was from 100 to $500{ }^{\circ} \mathrm{C}$ with $5{ }^{\circ} \mathrm{C} \mathrm{min}^{-1}$ as the heating rate. The tests were always repeated at least once to verify the results. Based on the repetition, we can roughly estimate the relative error of the experiment to be less than $5 \%$. Prior to the experiment, the samples were wrapped with quartz wool to avoid their displacement inside the reactor when the gas flow was switched on. The quartz wool also minimized the slip flow inside the reactor. The DCM conversions and $\mathrm{HCl}$ yields were calculated as follows:

$$
\begin{gathered}
\text { DCM conversion : } \mathrm{DCM}[\%]=100 \times \frac{C_{0}^{D C M}-C_{T}^{D C M}}{C_{0}^{D C M}} \\
\mathrm{HCl} \text { yield : } \mathrm{HCl}[\%]=100 \times \frac{C_{T}^{H C l}}{2 \times C_{0}^{D C M}}
\end{gathered}
$$

where $C_{0}^{D C M}$ is the inlet DCM concentration, $C_{T}^{D C M}$ and $C_{T}^{H C l}$ are the outlet concentrations of DCM and of $\mathrm{HCl}$ obtained as a function of temperature (T). 


\section{Conclusions}

The main aim of this work was to discover how well a catalyst powder will keep its characteristics after washcoating on a monolith substrate. Thus, three mixtures of $\mathrm{Al}_{2} \mathrm{O}_{3}$ and $\mathrm{SiO}_{2}$ oxides were prepared and washcoated on a cordierite monolith. The activities and selectivities of the monolith catalysts were studied before and after Pt (1 wt \%) impregnation in dichloromethane (DCM) total oxidation.

It was observed that the selected preparation procedure was successful since $\sim 10 \mathrm{wt} \%$ and $18 \mathrm{wt}$ $\%$ loadings of washcoat were obtained for $200 \mathrm{cpsi}$ and $600 \mathrm{cpsi}$ monoliths, respectively. The success of washcoating was also evidenced by the FESEM-EDS analysis. $\mathrm{N}_{2}$ physisorption demonstrated that the specific surface areas and the diameter as well as the volume of the pores determined for the sol were kept at the similar levels after washcoating of substrates.

The acidity of the support, and especially type of acid sites are affecting the formation of reaction byproducts in DCM oxidation. We observed that the total acidity of the washcoat (without Pt) was increasing with increased silica loading. Similarly, specific surface area was increased. When these two parameters were improved, the total amount of major byproducts $\left(\mathrm{CO}, \mathrm{CH}_{2} \mathrm{O}\right.$ and $\left.\mathrm{CH}_{3} \mathrm{Cl}\right)$ was decreased and $\mathrm{HCl}$ yield was increased. The addition of $\mathrm{Pt}$ improved the total oxidation in most of the cases.

The 200M10 monolith exhibited high conversion of DCM, and in addition, high $\mathrm{HCl}$ yield was obtained over Pt200M10, thus it was selected for the comparison with 600 cpsi monolith. The comparison between the two types of substrates (200 and $600 \mathrm{cpsi}$ ) showed that the latter presented better performance than 200M10. That is an evidence, in our experimental conditions, that the low value of OFA, $D_{h}$ and TIF and the high value of MIF and GSA are the key parameters influencing DCM oxidation. These were found with the monolith with 600 cpsi.

Author Contributions: Z.A. made the major part of the preparation, characterization, evaluation of the performance of the catalyst in DCM oxidation, literature survey and was responsible on the writing of the paper. A.D. made some material preparation and helped in characterization discussion. T.N. and S.P. were assisting to perform the activity tests and helped during the writing of this paper. M.Z. perform the characterisation of the monoliths and contributed to the discussion of the characterisation results for this paper. L.P.-R. contributed in the organization, and characterization of materials as well as discussion of the results. M.B., R.B., S.O. and R.L.K. are the supervisors of the doctoral thesis of Z.A., R.B., S.O. and R.L.K. also contributed in planning for the work related to the publication, evaluation of the results and/or helping during the writing of this paper.

Acknowledgments: The authors are grateful to Jorma Penttinen and Markus Riihimäki, whose were helping during this work in the characterization of the samples. The staff of the Center of Microscopy and Nanotechnology (University of Oulu, Finland) and Institute of Chemistry of Poitiers, Materials and natural resources (University of Poitiers, France) are acknowledged for the characterization as well. The work was done with the financial support of PHC Volubilis (No. 24618ZJ), and Oulu University Scholarship Foundation (Yliopiston Apteekin rahasto).

Conflicts of Interest: The authors declare no conflict of interest.

\section{References}

1. CEPA. Priority Substances List Assessment Report: Dichloromethane. Available online: http:/ / www.hc-sc.gc.ca/ewh-semt/alt_formats/hecs-sesc/pdf/pubs/contaminants/psl1-lsp1/ dichloromethane/dichloromethane-eng.pdf (accessed on 26 May 2014).

2. ATSDR. Toxicological Profile for Methylene Chloride. Available online: http://www.atsdr.cdc.gov/ ToxProfiles/tp14.pdf (accessed on 1 May 2016).

3. WHO. Dichloromethane. Available online: http://www.euro.who.int/_data/assets/pdf_file/0013/ 123061/AQG2ndEd_5_7Dichloromethane.pdf (accessed on 31 October 2016).

4. EPA. Toxicological Review of Dichloromethane. Available online: http:/ / www.epa.gov/iris/toxreviews / 0070tr.pdf (accessed on 31 October 2016).

5. Air Quality Guidelines for Europe. Available online: http://www.euro.who.int/_data/assets/pdf_file/ 0005/74732/E71922.pdf (accessed on 3 October 2013). 
6. The International Chemical Safety Cards. Available online: http://www.cdc.gov/niosh/ipcsneng/neng0058. html (accessed on 12 May 2014).

7. Matějová, L.; Topka, P.; Kaluža, L.; Pitkäaho, S.; Ojala, S.; Gaálová, J.; Keiski, R.L. Total oxidation of dichloromethane and ethanol over ceria-zirconia mixed oxide supported platinum and gold catalysts. Appl. Catal. B Environ. 2013, 142-143, 54-64. [CrossRef]

8. Pitkäaho, S.; Nevanperä, T.; Matejova, L.; Ojala, S.; Keiski, R.L. Oxidation of dichloromethane over Pt, Pd, Rh, and $\mathrm{V}_{2} \mathrm{O}_{5}$ catalysts supported on $\mathrm{Al}_{2} \mathrm{O}_{3}, \mathrm{Al}_{2} \mathrm{O}_{3}-\mathrm{TiO}_{2}$ and $\mathrm{Al}_{2} \mathrm{O}_{3}-\mathrm{CeO}_{2}$. Appl. Catal. B Environ. 2013, 138-139, 33-42. [CrossRef]

9. Ran, L.; Qin, Z.; Wang, Z.; Wang, X.; Dai, Q. Catalytic decomposition of $\mathrm{CH}_{2} \mathrm{Cl}_{2}$ over supported Ru catalysts. Catal. Commun. 2013, 37, 5-8. [CrossRef]

10. Van Den Brink, R.W.; Mulder, P.; Louw, R.; Sinquin, G.; Petit, C.; Hindermann, J. Catalytic Oxidation of Dichloromethane on $\gamma-\mathrm{Al}_{2} \mathrm{O}_{3}$ : A Combined Flow and Infrared Spectroscopic Study. J. Catal. 1998, 180, 153-160. [CrossRef]

11. Chen, Q.-Y.; Li, N.; Luo, M.-F.; Lu, J.-Q. Catalytic oxidation of dichloromethane over $\mathrm{Pt} / \mathrm{CeO} 2-\mathrm{Al}_{2} \mathrm{O}_{3}$ catalysts. Appl. Catal. B Environ. 2012, 127, 159-166. [CrossRef]

12. Wang, Y.; Liu, H.; Wang, S.-Y.; Luo, M.-F.; Lu, J. Remarkable enhancement of dichloromethane oxidation over potassium-promoted $\mathrm{Pt} / \mathrm{Al}_{2} \mathrm{O}_{3}$ catalysts. J. Catal. 2014, 311, 314-324. [CrossRef]

13. Van Den Brink, R.W.; Mulder, P.; Louw, R. Catalytic combustion of chlorobenzene on $\mathrm{Pt} / \gamma-\mathrm{Al}_{2} \mathrm{O}_{3}$ in the presence of aliphatic hydrocarbons. Catal. Today 1999, 54, 101-106. [CrossRef]

14. Padilla, A.M.; Corella, J.; Toledo, J.M. Total oxidation of some chlorinated hydrocarbons with commercial chromia based catalysts. Appl. Catal. B Environ. 1999, 22, 107-121. [CrossRef]

15. Corella, J.; Toledo, J.M.; Padilla, A.M. On the selection of the catalyst among the commercial platinum-based ones for total oxidation of some chlorinated hydrocarbons. Appl. Catal. B Environ. 2000, 27, 243-256. [CrossRef]

16. Wang, L.; Sakurai, M.; Kameyama, H. Catalytic oxidation of dichloromethane and toluene over platinum alumite catalyst. J. Hazard. Mater. 2008, 154, 390-395. [CrossRef] [PubMed]

17. Gu, Y.; Yang, Y.; Qiu, Y.; Sun, K.; Xu, X. Combustion of dichloromethane using copper-manganese oxides supported on zirconium modified titanium-aluminum catalysts. Catal. Commun. 2010, 12, 277-281. [CrossRef]

18. Maupin, I.; Pinard, L.; Mijoin, J.; Magnoux, P. Bifunctional mechanism of dichloromethane oxidation over $\mathrm{Pt} / \mathrm{Al}_{2} \mathrm{O}_{3}: \mathrm{CH}_{2} \mathrm{Cl}_{2}$ disproportionation over alumina and oxidation over platinum. J. Catal. 2012, 291, 104-109. [CrossRef]

19. Martino, M.; Rosal, R.; Sastre, H.; Díez, F.V. Hydrodechlorination of dichloromethane, trichloroethane, trichloroethylene and tetrachloroethylene over a sulfided Ni/Mo-alumina catalyst. Appl. Catal. B Environ. 1999, 20, 301-307. [CrossRef]

20. Papenmeier, D.M.; Rossin, J.A. Catalytic Oxidation of Dichloromethane, Chloroform, and Their Binary Mixtures over a Platinum Alumina Catalyst. Ind. Eng. Chem. Res. 1994, 33, 3094-3103. [CrossRef]

21. Wu, M.; Ung, K.C.; Dai, Q.; Wang, X. Catalytic combustion of chlorinated VOCs over $\mathrm{VOx} / \mathrm{TiO}_{2}$ catalysts. Catal. Commun. 2012, 18, 72-75. [CrossRef]

22. Aristizábal, B.; González, C.A.; Barrio, I.; Montes, M.; Montes de Correa, C. Screening of Pd and Ni supported on sol-gel derived oxides for dichloromethane hydrodechlorination. J. Mol. Catal. A Chem. 2004, 222, 189-198. [CrossRef]

23. Martínez, T.L.M.; Montes de Correa, C.; Odriozola, J.A.; Centeno, M.A. Synthesis and characterization of xerogel titania modified with Pd and Ni. J. Mol. Catal. A Chem. 2006, 253, 252-260. [CrossRef]

24. Windawi, H.; Zhang, Z.C. Catalytic destruction of halogenated air toxins and the effect of admixture with VOCs. Catal. Today 1996, 30, 99-105. [CrossRef]

25. Dai, Q.; Wang, X.; Lu, G. Low-temperature catalytic destruction of chlorinated VOCs over cerium oxide. Catal. Commun. 2007, 8, 1645-1649. [CrossRef]

26. El Assal, Z.; Pitkäaho, S.; Ojala, S.; Maache, R.; Bensitel, M.; Pirault-Roy, L.; Brahmi, R.; Keiski, R.L. Total Oxidation of Dichloromethane Over Metal Oxide Catalysts. Top. Catal. 2013, 56, 679-687. [CrossRef]

27. Van Der Avert, P.; Weckhuysen, B.M. Low-temperature catalytic destruction of $\mathrm{CCl}_{4}, \mathrm{CHCl}_{3}$ and $\mathrm{CH}_{2} \mathrm{Cl}_{2}$ over basic oxides. Phys. Chem. Chem. Phys. 2004, 6, 5256-5262. [CrossRef] 
28. Pinard, L.; Mijoin, J.; Magnoux, P.; Guisnet, M. Dichloromethane transformation over bifunctional PtFAU catalysts. Influence of the acidobasicity of the zeolite. Comptes Rendus Chim. 2005, 8, 457-463. [CrossRef]

29. Pinard, L.; Mijoin, J.; Magnoux, P.; Guisnet, M. Oxidation of chlorinated hydrocarbons over Pt zeolite catalysts 1-mechanism of dichloromethane transformation over PtNaY catalysts. J. Catal. 2003, 215, $234-244$. [CrossRef]

30. Pinard, L.; Mijoin, J.; Ayrault, P.; Canaff, C.; Magnoux, P. On the mechanism of the catalytic destruction of dichloromethane over Pt zeolite catalysts. Appl. Catal. B Environ. 2004, 51, 1-8. [CrossRef]

31. Koyer-Gołkowska, A.; Musialik-Piotrowska, A.; Rutkowski, J.D. Oxidation of chlorinated hydrocarbons over Pt-Pd-based catalyst. Part 1. Chlorinated methanes. Catal. Today 2004, 90, 133-138. [CrossRef]

32. Gutierrez-ortiz, J.; López-Fonseca, R.; Aurrekoetxea, U.; González-Velasco, J. Low-temperature deep oxidation of dichloromethane and trichloroethylene by H-ZSM-5-supported manganese oxide catalysts. J. Catal. 2003, 218, 148-154. [CrossRef]

33. López-Fonseca, R.; de Rivas, B.; Gutiérrez-Ortiz, J.I.; Aranzabal, A.; González-Velasco, J.R. Enhanced activity of zeolites by chemical dealumination for chlorinated VOC abatement. Appl. Catal. B Environ. 2003, 41, 31-42. [CrossRef]

34. Pitkäaho, S.; Ojala, S.; Maunula, T.; Savimäki, A.; Kinnunen, T.; Keiski, R.L. Oxidation of dichloromethane and perchloroethylene as single compounds and in mixtures. Appl. Catal. B Environ. 2011, 102, $395-403$. [CrossRef]

35. El Assal, Z.; Ojala, S.; Pitkäaho, S.; Pirault-Roy, L.; Darif, B.; Comparot, J.-D.; Bensitel, M.; Keiski, R.L.; Brahmi, R. Comparative study on the support properties in the total oxidation of dichloromethane over Pt catalysts. Chem. Eng. J. 2017, 313, 1010-1022. [CrossRef]

36. Heck, R.M.; Gulati, S.; Farrauto, R.J. The application of monoliths for gas phase catalytic reactions. Chem. Eng. J. 2001, 82, 149-156. [CrossRef]

37. Cybulski, A.; Moulijn, J.A. Structured Catalysts and Reactors, 2nd ed.; Cybulski, A., Moulijn, J.A., Eds.; Marcel Dekker: New York, NY, USA, 1998; ISBN 0824799216.

38. Giroux, T.; Hwang, S.; Liu, Y.; Ruettinger, W.; Shore, L. Monolithic structures as alternatives to particulate catalysts for the reforming of hydrocarbons for hydrogen generation. Appl. Catal. B Environ. 2005, 56, 95-110. [CrossRef]

39. Williams, J.L. Monolith structures, materials, properties and uses. Catal. Today 2001, 69, 3-9. [CrossRef]

40. Avila, P.; Montes, M.; Miró, E.E. Monolithic reactors for environmental applications. Chem. Eng. J. 2005, 109, 11-36. [CrossRef]

41. Sing, K.S.W. Reporting physisorption data for gas/solid systems with special reference to the determination of surface area and porosity. Pure Appl.Chem. 1982, 54, 2201-2218. [CrossRef]

42. Thommes, M. Physical Adsorption Characterization of Nanoporous Materials. Chem. Ing. Tech. 2010, 82, 1059-1073. [CrossRef]

43. Berteau, P.; Delmon, B. Modified Aluminas: Relationship between activity in 1-butanol dehydration and acidity measured by $\mathrm{NH}_{3}$ TPD. Catal. Today 1989, 5, 121-137. [CrossRef]

44. Keshavarz, A.R.; Rezaei, M.; Yaripour, F. Preparation of nanocrystalline $\gamma-\mathrm{Al}_{2} \mathrm{O}_{3}$ catalyst using different procedures for methanol dehydration to dimethyl ether. J. Nat. Gas Chem. 2011, 20, 334-338. [CrossRef]

45. Saad, F.; Comparot, J.D.; Brahmi, R.; Bensitel, M.; Pirault-Roy, L. Influence of acid-base properties of the support on the catalytic performances of Pt-based catalysts in a gas-phase hydrogenation of acetonitrile. Appl. Catal. A Gen. 2017, 544, 1-9. [CrossRef]

46. Roy, S.; Heibel, A.K.; Liu, W.; Boger, T. Design of monolithic catalysts for multiphase reactions. Chem. Eng. Sci. 2004, 59, 957-966. [CrossRef]

47. Nijhuis, T.A.; Kreutzer, M.T.; Romijn, A.C.J.; Kapteijn, F.; Moulijn, J.A. Monolithic catalysts as efficient three-phase reactors. Chem. Eng. Sci. 2001, 56, 823-829. [CrossRef]

48. Jiahai, B.; Lucun, G. Effects of Chemical Treatments on Thermal Expansion Properties of Cordierite Ceramics. J. Wuhan Univ. Technol. Sci. Ed. 2006, 21, 100-103. [CrossRef]

49. Pitkäaho, S.; Matejova, L.; Ojala, S.; Gaalova, J.; Keiski, R.L. Oxidation of perchloroethylene-Activity and selectivity of $\mathrm{Pt}, \mathrm{Pd}, \mathrm{Rh}$, and $\mathrm{V}_{2} \mathrm{O}_{5}$ catalysts supported on $\mathrm{Al}_{2} \mathrm{O}_{3}, \mathrm{Al}_{2} \mathrm{O}_{3}-\mathrm{TiO}_{2}$ and $\mathrm{Al}_{2} \mathrm{O}_{3}-\mathrm{CeO}_{2}$. Appl. Catal. B Environ. 2012, 113-114, 150-159. [CrossRef] 
50. De Rivas, B.; López-Fonseca, R.; Gutiérrez-Ortiz, M.A.; Gutiérrez-Ortiz, J.I. Role of water and other H-rich additives in the catalytic combustion of 1,2-dichloroethane and trichloroethylene. Chemosphere 2009, 75, 1356-1362. [CrossRef] [PubMed]

51. Ojala, S. Catalytic Oxidation of Volatile Organic Compounds and Malodorous Organic Compounds. Ph.D. Thesis, University of Oulu, Oulu, Finland, 2005. 